AperTO - Archivio Istituzionale Open Access dell'Università di Torino

\title{
New nitric oxide or hydrogen sulfide releasing aspirins
}

\section{This is the author's manuscript}

Original Citation:

Availability:

This version is available http://hdl.handle.net/2318/93297

since 2015-12-22T11:43:03Z

Published version:

DOI:10.1021/jm2004514

Terms of use:

Open Access

Anyone can freely access the full text of works made available as "Open Access". Works made available under a Creative Commons license can be used according to the terms and conditions of said license. Use of all other works requires consent of the right holder (author or publisher) if not exempted from copyright protection by the applicable law. 


\section{SUPPORTING INFORMATION}

\section{New Nitric Oxide or Hydrogen Sulfide Releasing Aspirins}

Loretta Lazzarato, ${ }^{1}$ Konstantin Chegaev, ${ }^{1}$ Elisabetta Marini, ${ }^{1}$ Barbara Rolando, ${ }^{1}$ Emily Borretto, ${ }^{1}$ Stefano Guglielmo, ${ }^{1}$ Sony Joseph, ${ }^{1}$ Antonella Di Stilo, ${ }^{1}$ Roberta Fruttero, ${ }^{1}$ Alberto Gasco, ${ }^{1, *}$

${ }^{1}$ Dipartimento di Scienza e Tecnologia del Farmaco, Università degli Studi di Torino, Via Pietro Giuria 9, 10125 Torino, Italy

Table of contents (total of 9 pages), page S1

Supplementary experimental section, pages S2-S8

Supplementary references, page S9 


\section{Supplementary Experimental Section}

Chemistry. ${ }^{1} \mathrm{H}$ and ${ }^{13} \mathrm{C}-\mathrm{NMR}$ spectra were recorded on a Bruker Avance 300 at 300 and $75 \mathrm{MHz}$ respectively, using $\mathrm{SiMe}_{4}$ as the internal standard. Low resolution mass spectra were recorded with a Finnigan-Mat TSQ-700. Melting points were determined with a capillary apparatus (Büchi 540). Flash column chromatography was performed on silica gel (Merck Kieselgel 60, 230-400 mesh ASTM); PE stands for 40-60 petroleum ether. The progress of the reactions was followed by thin layer chromatography (TLC) on $5 \times 20 \mathrm{~cm}$ plates with a layer thickness of $0.2 \mathrm{~mm}$. Anhydrous magnesium sulfate was used as the drying agent for the organic phases. Organic solvents were removed under vacuum at $30{ }^{\circ} \mathrm{C}$. Elemental analyses $(\mathrm{C}, \mathrm{H}, \mathrm{N})$ were performed by REDOX (Monza), and the results are within $\left(0.4 \%\right.$ of the theoretical values. Compounds $\mathbf{7 a},{ }^{1} \mathbf{7 b},{ }^{2} \mathbf{7} \mathbf{c}^{3}, \mathbf{7 d}^{3}, \mathbf{1 0}^{4}$ and $\mathbf{1 3}^{5}$ were obtained as described elsewhere.

General procedure for the preparation of 8a-d. To a solution of the appropriate alcohol ( $2.5 \mathrm{mmol})$ and chloromethylchloroformate $(0.25 \mathrm{~mL}, 2.7 \mathrm{mmol})$ in dry $\mathrm{CH}_{2} \mathrm{Cl}_{2}(15 \mathrm{~mL})$, stirred at $-15{ }^{\circ} \mathrm{C}$, a solution of Py $(0.22 \mathrm{~mL}, 2.7 \mathrm{mmol})$ in dry $\mathrm{CH}_{2} \mathrm{Cl}_{2}(10 \mathrm{~mL})$ was added dropwise. At the end of the addition the ice-salt bath was removed and the reaction mixture was allowed to reach room temperature. After 15 min the solvent was removed and obtained oil was purified by flash chromatography. Chromatographic eluents and yields of the products were as follow.

Chloromethyl-3-nitrooxypropyl carbonate (8a). Eluent $\left(\mathrm{PE}^{-} \mathrm{CH}_{2} \mathrm{Cl}_{2} 7 / 3 \mathrm{v} / \mathrm{v}\right)$; colourless oil; yield 83\%. ${ }^{1} \mathrm{H}-\mathrm{NMR}\left(\mathrm{CDCl}_{3}\right) \delta 2.15\left(\mathrm{qi}, 2 \mathrm{H},-\mathrm{CH}_{2} \mathrm{CH}_{2} \mathrm{ONO}_{2}\right), 4.35\left(\mathrm{t}, 2 \mathrm{H},-\mathrm{OCH}_{2} \mathrm{CH}_{2}\right.$ ) $), 4.58(\mathrm{t}, 2 \mathrm{H}$, $\left.-\mathrm{CH}_{2} \mathrm{ONO}_{2}\right), 5.74\left(\mathrm{~s}, 2 \mathrm{H},-\mathrm{CH} \mathrm{H}_{2} \mathrm{Cl}\right) .{ }^{13} \mathrm{C}-\mathrm{NMR}\left(\mathrm{CDCl}_{3}\right) \delta 26.3,64.9,69.1,72.3,153.2$.

Chloromethyl-5,6-dinitrooxypropyl carbonate (8b). Eluent $\left(\mathrm{PE}^{-\mathrm{CH}_{2} \mathrm{Cl}_{2}} 1 / 1 \mathrm{v} / \mathrm{v}\right)$; colourless oil; yield 80\%. ${ }^{1} \mathrm{H}-\mathrm{NMR}\left(\mathrm{CDCl}_{3}\right) \delta 4.44(\mathrm{dd}, 1 \mathrm{H},-\mathrm{CH} H \mathrm{O}-), 4.56-4.70\left(\mathrm{~m}, 2 \mathrm{H},-\mathrm{CH} H \mathrm{ONO}_{2}+,-\mathrm{CH} H \mathrm{O}-\right)$, $4.81\left(\mathrm{dd}, 1 \mathrm{H}\right.$, , $\left.-\mathrm{CH} H \mathrm{ONO}_{2}\right), 5.48-5.54\left(\mathrm{~m}, 1 \mathrm{H},-\mathrm{CHONO}_{2}\right), 5.72-5.77\left(\mathrm{~m}, 2 \mathrm{H},-\mathrm{C} \mathrm{H}_{2} \mathrm{Cl}\right) .{ }^{13} \mathrm{C}-\mathrm{NMR}$ $\left(\mathrm{CDCl}_{3}\right) \delta$ 64.6, 68.2, 72.6, 75.6, 152.9. 
Chloromethyl-4-(3-nitrooxypropyl)phenyl carbonate (8c). Eluent $\left(\mathrm{PE} / \mathrm{CH}_{2} \mathrm{Cl}_{2}\right.$ 8/2 v/v); colourless oil, which solidified on standing in freezer; yield $75 \%$. ${ }^{1} \mathrm{H}-\mathrm{NMR}\left(\mathrm{CDCl}_{3}\right) \delta 2.05(\mathrm{~m}, 2 \mathrm{H}$, $-\mathrm{CH}_{2} \mathrm{CH}_{2} \mathrm{ONO}_{2}$ ), $2.75\left(\mathrm{t}, 2 \mathrm{H},-\mathrm{CH}_{2} \mathrm{CH}_{2} \mathrm{CH}_{2} \mathrm{ONO}_{2}\right), 4.45\left(\mathrm{t}, 2 \mathrm{H},-\mathrm{CH}_{2} \mathrm{ONO}_{2}\right), 5.82\left(\mathrm{~s}, 2 \mathrm{H},-\mathrm{CH} \mathrm{H}_{2} \mathrm{Cl}\right), 7.13$ $-7.26\left(\mathrm{~m}, 4 \mathrm{H}, \mathrm{C}_{6} \mathrm{H}_{4}\right) .{ }^{13} \mathrm{C}-\mathrm{NMR}\left(\mathrm{CDCl}_{3}\right) \delta 28.3,31.1,72.1,72.5,120.9,129.5,138.6,149.2,152.1$.

4-(2,3-Bis(nitrooxy)propyl)phenyl chloromethyl carbonate (8d). Eluent $\left(\mathrm{PE} / \mathrm{CH}_{2} \mathrm{Cl}_{2} \quad 6 / 4 \mathrm{v} / \mathrm{v}\right)$; yellowish oil; yield 50\%. ${ }^{1} \mathrm{H}-\mathrm{NMR}\left(\mathrm{CDCl}_{3}\right) \delta 2.99-3.14\left(\mathrm{~m}, 2 \mathrm{H},-\mathrm{CH}_{2} \mathrm{CH}-\right), 4.44(\mathrm{dd}, 1 \mathrm{H}$, $\left.-\mathrm{CHHONO}_{2}\right), 4.73\left(\mathrm{dd}, 1 \mathrm{H},-\mathrm{CH} H \mathrm{ONO}_{2}\right), 5.40-5.47\left(\mathrm{~m}, 1 \mathrm{H},-\mathrm{CHONO}\right.$ ), $5.82\left(\mathrm{~s}, 2 \mathrm{H},-\mathrm{CH} \mathrm{Cl}_{2}\right), 7.20-$ $7.30\left(\mathrm{~m}, 4 \mathrm{H}, \mathrm{C}_{6} \mathrm{H}_{4}\right) .{ }^{13} \mathrm{C}-\mathrm{NMR}\left(\mathrm{CDCl}_{3}\right) \delta 34.9,70.0,72.6,79.2,121.5,130.5,132.6,150.2,151.9 . \mathrm{MS}$ EI: $350(\mathrm{M})^{+}$.

5-(4-(2-Hydroxyethoxy)phenyl)-3H-1,2-dithiole-3-thione (12). To a solution of $\mathrm{Ph}_{3} \mathrm{P}(0.28 \mathrm{~g}, 1.1$ mmol) in dry THF $(10 \mathrm{~mL})$, stirred under positive nitrogen pressure at $-15^{\circ} \mathrm{C}$, DIAD $(0.22 \mathrm{~mL}, 1.1$ mmol) was added. Reaction mixture was stirred for $15 \mathrm{~min}$, until white precipitate formed and $\mathbf{1 0}(0.20$ g, $0.90 \mathrm{mmol})$ was added, followed by 2-(tetrahydropyran-2-yloxy)ethanol $(0.13 \mathrm{~g}, 0.90 \mathrm{mmol})$. The resulting mixture was stirred for 24 hours at room temperature, then was poured in $\mathrm{H}_{2} \mathrm{O}(10 \mathrm{~mL})$ and extracted with $\mathrm{Et}_{2} \mathrm{O}(3 \times 10 \mathrm{~mL})$. The combined organic layers were washed with brine, dried, filtered and concentrated under reduced pressure. The crude product was purified by flash chromatography (PE/acetone 9/1 v/v) to give 5-(4-(2-(tetrahydropyran-2-yloxy)ethoxy)phenyl)-3H-1,2-dithiole-3-thione (11) as a reddish-brown oil; yield $70 \% .{ }^{1} \mathrm{H}-\mathrm{NMR}\left(\mathrm{CDCl}_{3}\right) \delta 1.52-1.89(\mathrm{~m}, 6 \mathrm{H}, 3 \mathrm{CH}$ pyran$), 3.51-3.58$ (m, 1H), 3.81-4.25 (m, 5H), ( $\left.\mathrm{CH}_{2} \mathrm{Opyran,} \mathrm{-OCH} \mathrm{CH}_{2} \mathrm{O}-\right), 4.70-7.72(\mathrm{~m}, 1 \mathrm{H},-\mathrm{OCHO}-), 7.02(\mathrm{~d}, 2 \mathrm{H}$, $\left.\mathrm{C}_{6} \mathrm{H}_{4}\right), 7.40\left(\mathrm{~s}, 1 \mathrm{H}, \mathrm{C}_{3} \mathrm{~S}_{3} H\right), 7.62\left(\mathrm{~d}, 2 \mathrm{H}, \mathrm{C}_{6} \mathrm{H}_{4}\right) .{ }^{13} \mathrm{C}-\mathrm{NMR}\left(\mathrm{CDCl}_{3}\right) \delta$ 19.4, 25.4, 30.5, 62.3, 65.6, 67.8, 99.1, 115.5, 124.2, 128.6, 134.6, 162.3, 173.1, 215.1. MS (CI) $m / z 355(\mathrm{M}+1)^{+}$.

11 (0.44 g; $1.20 \mathrm{mmol})$ was dissolved in $\mathrm{MeOH}(15 \mathrm{~mL})$ and a catalytic amount of PPTS was added. The resulting mixture was heated at $55^{\circ} \mathrm{C}$ for $2 \mathrm{~h}$, then concentrated under reduced pressure. The crude product was purified by flash chromatography (PE/acetone $6 / 4 \mathrm{v} / \mathrm{v}$ ) to give a reddish solid, which was recrystallized from EtOH to give the title compound as a yellowish-orange solid; yield $40 \%$; m.p. 117.5 ${ }^{\circ} \mathrm{C}\left(\right.$ from EtOH). ${ }^{1} \mathrm{H}-\mathrm{NMR}\left(\mathrm{CDCl}_{3}\right) \delta 2.12(\mathrm{sbr}, 1 \mathrm{H}, \mathrm{OH}), 4.02(\mathrm{t}, 2 \mathrm{H}), 4.16(\mathrm{t}, 2 \mathrm{H})\left(-\mathrm{OCH} \mathrm{C}_{2} \mathrm{CH}_{2} \mathrm{OH}\right)$, 
$7.00\left(\mathrm{~d}, 2 \mathrm{H}, \mathrm{C}_{6} \mathrm{H}_{4}\right), 7.39\left(\mathrm{~s}, 1 \mathrm{H}, \mathrm{C}_{3} \mathrm{~S}_{3} H\right), 7.61\left(\mathrm{~d}, 2 \mathrm{H}, \mathrm{C}_{6} \mathrm{H}_{4}\right) .{ }^{13} \mathrm{C}-\mathrm{NMR}\left(\mathrm{CDCl}_{3}\right) \delta$ 61.2, 69.6, 115.5, 124.5, 128.6, 134.7, 162.0, 172.9, 215.1. MS (CI) $m / z 271(\mathrm{M}+1)^{+}$.

General procedure for the preparation of 9a-d, 14. To a solution of acetylsalicylic acid (0.22 g, 1.2 $\mathrm{mmol})$ in DMF $(5 \mathrm{~mL}) \mathrm{Cs}_{2} \mathrm{CO}_{3}(0.20 \mathrm{~g}, 0.60 \mathrm{mmol})$ was added and the resulting mixture was vigorously stirred for $15 \mathrm{~min}$; then the appropriate chloromethylcarbonate $(1.0 \mathrm{mmol})$ was added and reaction mixture was stirred at room temparature for $24 \mathrm{~h}$. The reaction mixture was diluted with $\mathrm{Et}_{2} \mathrm{O}(25 \mathrm{~mL})$ and washed with $\mathrm{H}_{2} \mathrm{O}$, a saturated solution of $\mathrm{NaHCO}_{3}$ and brine. The organic layer was dried, filtered and concentrated under reduced pressure. The crude product so obtained was purified by flash chromatography. Chromatographic eluents and yields of the products were as follow.

[(3-Nitrooxypropyl)carbonyl]oxymethyl 2-(acetyloxy)benzoate (9a). Eluent (PE/EtOAc 9/1 v/v); colourless oil; yield 75\%. ${ }^{1} \mathrm{H}-\mathrm{NMR}\left(\mathrm{CDCl}_{3}\right)$ $\delta: 2.12\left(\mathrm{qi}, 2 \mathrm{H},-\mathrm{CH}_{2} \mathrm{CH}_{2} \mathrm{ONO}_{2}\right), 2.36\left(\mathrm{~s}, 3 \mathrm{H},-\mathrm{CH}_{3}\right), 4.31$ $\left(\mathrm{t}, 2 \mathrm{H},-\mathrm{OCH}_{2} \mathrm{CH}_{2}-\right), 4.55\left(\mathrm{t}, 2 \mathrm{H},-\mathrm{CH}_{2} \mathrm{ONO}_{2}\right), 5.95\left(\mathrm{~s}, 2 \mathrm{H},-\mathrm{OCH} \mathrm{H}_{2} \mathrm{O}-\right), 7.12(\mathrm{~d}, 1 \mathrm{H}), 7.34(\mathrm{t}, 1 \mathrm{H}), 7.61(\mathrm{t}$, 1H), $8.08(\mathrm{~d}, 1 \mathrm{H})\left(\mathrm{C}_{6} \mathrm{H}_{4}\right) .{ }^{13} \mathrm{C}-\mathrm{NMR}\left(\mathrm{CDCl}_{3}\right) \delta: 21.0,26.3,64.4,69.2,82.2,121.7,124.1,126.2,132.5$, 134.9, 151.2, 153.8, 162.7, 168.2. MS (CI) $m / z 358(\mathrm{M}+1)^{+}$. Anal. $\left(\mathrm{C}_{14} \mathrm{H}_{15} \mathrm{NO}_{10}\right)$ : C, H, N.

\section{([2,3-Bis(nitrooxy)propyl]carbonyl)oxymethyl 2-(acetyloxy)benzoate (9b). Eluent (PE/EtOAc 8/2} v/v); colourless oil; yield 29\%. ${ }^{1} \mathrm{H}-\mathrm{NMR}\left(\mathrm{CDCl}_{3}\right)$ \&: $2.36\left(\mathrm{~s}, 3 \mathrm{H},-\mathrm{CH}_{3}\right), 4.39\left(\mathrm{dd}, 1 \mathrm{H},-\mathrm{CH} H \mathrm{ONO}_{2}\right)$, $4.54\left(\mathrm{dd}, 1 \mathrm{H},-\mathrm{CH} H \mathrm{ONO}_{2}\right), 4.64$ (dd, 1H, -CHHO-), 4.80 (dd, 1H, -CHHO-), 5.45-5.51 (m, 1H, $\left.-\mathrm{CHONO}_{2}\right), 5.97\left(\mathrm{~s}, 2 \mathrm{H},-\mathrm{OCH}_{2} \mathrm{O}\right), 7.13(\mathrm{~d}, 1 \mathrm{H}), 7.35(\mathrm{t}, 1 \mathrm{H}), 7.62(\mathrm{t}, 1 \mathrm{H}), 8.08(\mathrm{~d}, 1 \mathrm{H})\left(\mathrm{C}_{6} \mathrm{H}_{4}\right) .{ }^{13} \mathrm{C}-$ $\operatorname{NMR}\left(\mathrm{CDCl}_{3}\right) \delta: 20.9,64.3,68.2,75.7,82.5,121.6,124.1,126.3,132.3,135.0,151.2,153.5,162.6$ 169.7. MS (CI) $m / z 419(\mathrm{M}+1)^{+}$. Anal. $\left(\mathrm{C}_{14} \mathrm{H}_{14} \mathrm{~N}_{2} \mathrm{O}_{13}\right): \mathrm{C}, \mathrm{H}, \mathrm{N}$.

[4-(3-Nitrooxypropyl)phenoxycarbonyl]oxymethyl 2-(acetyloxy)benzoate (9c). Eluent (PE/EtOAc 8/2 v/v); white solid; m.p. 52.5-53 ${ }^{\circ} \mathrm{C}$ (from $i \operatorname{Pr}_{2} \mathrm{O}$ ); yield 64\%. ${ }^{1} \mathrm{H}-\mathrm{NMR}\left(\mathrm{CDCl}_{3}\right) \delta: 2.04$ (qi, $2 \mathrm{H}$, $\left.-\mathrm{CH}_{2} \mathrm{CH}_{2} \mathrm{ONO}_{2}\right), 2.37\left(\mathrm{~s}, 3 \mathrm{H},-\mathrm{CH}_{3}\right), 2.74\left(\mathrm{t}, 2 \mathrm{H},-\mathrm{CH}_{2} \mathrm{CH}_{2} \mathrm{CH}_{2} \mathrm{ONO}_{2}\right), 4.45\left(\mathrm{t}, 2 \mathrm{H},-\mathrm{CH}_{2} \mathrm{ONO}_{2}\right), 6.05(\mathrm{~s}$, $\left.2 \mathrm{H},-\mathrm{OCH}_{2} \mathrm{O}-\right), 7.13-7.22(\mathrm{~m}, 5 \mathrm{H}), 7.37(\mathrm{t}, 1 \mathrm{H}), 7.65(\mathrm{t}, 1 \mathrm{H}), 8.11(\mathrm{~d}, 1 \mathrm{H})\left(2 \mathrm{C}_{6} \mathrm{H}_{4}\right) .{ }^{13} \mathrm{C}-\mathrm{NMR}\left(\mathrm{CDCl}_{3}\right) \delta$ : 21.0, 28.3, 31.1, 72.1, 82.5, 121.0, 121.7, 124.1, 126.2, 129.5, 132.3, 135.0, 138.4, 149.3, 151.2, 152.7, 162.7, 169.7. MS (CI) $m / z 434(\mathrm{M}+1)^{+}$. Anal. $\left(\mathrm{C}_{20} \mathrm{H}_{19} \mathrm{NO}_{10}\right): \mathrm{C}, \mathrm{H}, \mathrm{N}$. 
[4-[2,3-Bis(nitrooxy)propyl]phenoxycarbonyl]oxymethyl 2-(acetyloxy)benzoate (9d). Eluent (PE/EtOAc 8/2 v/v); colourless oil; yield 51\%. ${ }^{1} \mathrm{H}-\mathrm{NMR}\left(\mathrm{CDCl}_{3}\right) \delta 2.36\left(\mathrm{~s}, 3 \mathrm{H},-\mathrm{CH}_{3}\right), 2.97-3.13(\mathrm{~m}$, 2H, $\left.-\mathrm{CH}_{2} \mathrm{CH}-\right), 4.43\left(\mathrm{dd}, 1 \mathrm{H},-\mathrm{CH} H \mathrm{ONO}_{2}\right), 4.73\left(\mathrm{dd}, 1 \mathrm{H},-\mathrm{CH} H \mathrm{ONO}_{2}\right)$, 5.38-5.46 (m, $\left.1 \mathrm{H},-\mathrm{CHONO}_{2}\right)$, $6.05\left(\mathrm{~s}, 2 \mathrm{H},-\mathrm{OCH}_{2} \mathrm{O}-\right), 7.13-7.38(\mathrm{~m}, 6 \mathrm{H}), 7.61(\mathrm{t}, 1 \mathrm{H}), 8.11(\mathrm{~d}, 1 \mathrm{H})\left(2 \mathrm{C}_{6} \mathrm{H}_{4}\right) .{ }^{13} \mathrm{C}-\mathrm{NMR}\left(\mathrm{CDCl}_{3}\right) \delta$ 21.0, 34.9, 70.0, 79.2, 82.5, 121.7, 124.1, 126.2, 130.5, 132.3, 135.0, 150.3, 151.3, 152.5, 162.7, 169.7 MS (CI) $m / z 495(\mathrm{M}+1)^{+}$. Anal. $\left(\mathrm{C}_{20} \mathrm{H}_{18} \mathrm{~N}_{2} \mathrm{O}_{13}\right): \mathrm{C}, \mathrm{H}, \mathrm{N}$.

(Ethylthiocarbonyl)oxymethyl 2-(acetyloxy)benzoate (14). Eluent (PE/EtOAc 8/2 v/v); colourless oil; yield 87\%. ${ }^{1} \mathrm{H}-\mathrm{NMR}\left(\mathrm{CDCl}_{3}\right) \delta: 1.33\left(\mathrm{t}, 3 \mathrm{H},-\mathrm{CH}_{2} \mathrm{CH}_{3}\right), 2.36\left(\mathrm{~s}, 3 \mathrm{H},-\mathrm{CH}_{3}\right), 2.90\left(\mathrm{q}, 2 \mathrm{H},-\mathrm{CH}_{2} \mathrm{CH}_{3}\right), 6.00$ $\left(\mathrm{s}, 2 \mathrm{H},-\mathrm{OCH}_{2} \mathrm{O}-\right), 7.13(\mathrm{~d}, 1 \mathrm{H}), 7.35(\mathrm{t}, 1 \mathrm{H}), 7.60(\mathrm{t}, 1 \mathrm{H}), 8.07(\mathrm{~d}, 1 \mathrm{H})\left(\mathrm{C}_{6} \mathrm{H}_{4}\right) .{ }^{13} \mathrm{C}-\mathrm{NMR}\left(\mathrm{CDCl}_{3}\right) \delta$ : $14.8,21.0,25.5,80.5,121.9,124.1,126.1,132.3,134.8,151.2,162.7,169.6,170.8$. MS (EI) $m / z 298$ $(\mathrm{M})^{+}$.

General procedure for the preparation of $16 \mathbf{a}$ and $16 \mathbf{b} . \mathrm{SO}_{2} \mathrm{Cl}_{2}(0.88 \mathrm{~mL}, 10.9 \mathrm{mmol})$ was added dropwise to $14(3.24 \mathrm{~g}, 10.9 \mathrm{mmol})$ stirred at $0{ }^{\circ} \mathrm{C}$. The mixture was allowed to reach room temperature and stirred for 1 hour. Then the reaction mixture was concentrated under reduced pressure to give $\mathbf{1 5}$ as colourless oil that was used in the next synthetic step without further purification.

To a solution of $15(0.85 \mathrm{~g}, 3.1 \mathrm{mmol})$ in $\mathrm{CH}_{2} \mathrm{Cl}_{2}(30 \mathrm{~mL})$, stirred at $-15{ }^{\circ} \mathrm{C}$, a solution of the appropriate hydroxy derivative $(2.6 \mathrm{mmol})$ and $\mathrm{N}$-methylmorpholine $(0.31 \mathrm{~mL}, 2.6 \mathrm{mmol})$ in $\mathrm{CH}_{2} \mathrm{Cl}_{2}$ $(30 \mathrm{~mL})$ was added dropwise. The reaction mixture was stirred for 1 hour at $-15{ }^{\circ} \mathrm{C}$, then for 24 hours at room temperature, then was poured in $\mathrm{H}_{2} \mathrm{O}(20 \mathrm{~mL})$ and extracted with $\mathrm{CH}_{2} \mathrm{Cl}_{2}(3 \times 20 \mathrm{~mL})$. The combined organic layers were washed with brine, dried, filtered and concentrated under reduced pressure. The crude product was purified by flash chromatography. Chromatographic eluents and yields of the products were as follow.

((4-(3-Thioxo-3H-1,2-dithiol-5-yl)phenoxy)carbonyloxy)methyl 2-acetoxybenzoate (16a). Eluent $(\mathrm{PE} /$ EtOAc 8/2 v/v); reddish-brown solid, which was recrystallized from EtOH to give the title compound as a yellowish-orange solid; yield $30 \%$; m.p. 103.5-104 ${ }^{\circ} \mathrm{C}$ (from EtOH). ${ }^{1} \mathrm{H}-\mathrm{NMR}\left(\mathrm{CDCl}_{3}\right)$ $\delta 2.37\left(\mathrm{~s}, 3 \mathrm{H},-\mathrm{CH}_{3}\right), 6.07\left(\mathrm{~s}, 2 \mathrm{H},-\mathrm{OCH}_{2} \mathrm{O}-\right), 7.15\left(\mathrm{~d}, 1 \mathrm{H}, \mathrm{C}_{6} \mathrm{H}_{4}\right), 7.33-7.40\left(\mathrm{~m}, 4 \mathrm{H}, 2 \mathrm{C}_{6} \mathrm{H}_{4}+\mathrm{C}_{3} H \mathrm{~S}_{3}\right)$, 
$7.61-7.71(\mathrm{~m}, 3 \mathrm{H}), 8.13(\mathrm{~d}, 1 \mathrm{H})\left(2 \mathrm{C}_{6} \mathrm{H}_{4}\right) .{ }^{13} \mathrm{C}-\mathrm{NMR}\left(\mathrm{CDCl}_{3}\right) \delta 21.0,82.6,121.5,122.2,124.1,126.2$, $128.4,129.8,132.3,135.0,136.2,151.3,151.8,153.3,162.6,169.8,171.4,215.5 . \mathrm{MS}(\mathrm{CI}) \mathrm{m} / z 463$ $(\mathrm{M}+1)^{+}$. Anal. $\left(\mathrm{C}_{20} \mathrm{H}_{14} \mathrm{O}_{7} \mathrm{~S}_{3}\right): \mathrm{C}, \mathrm{H}, \mathrm{N}$.

\section{((2-(4-(3-Thioxo-3H-1,2-dithiol-5-yl)phenoxy)ethoxy)carbonyloxy)methyl}

2-acetoxybenzoate

(16b). Eluent (PE/EtOAc 75/25 v/v); reddish-brown solid, which was recrystallized from EtOH to give the title compound as a yellowish-orange solid; yield $20 \%$; m.p. $105{ }^{\circ} \mathrm{C}$ (from EtOH). ${ }^{1} \mathrm{H}-\mathrm{NMR}$ $\left(\mathrm{CDCl}_{3}\right) \delta 2.36\left(\mathrm{~s}, 3 \mathrm{H},-\mathrm{CH}_{3}\right), 4.28(\mathrm{t}, 2 \mathrm{H}), 4.58(\mathrm{t}, 2 \mathrm{H})\left(-\mathrm{OCH}_{2} \mathrm{CH}_{2} \mathrm{O}-\right), 5.98\left(\mathrm{~s}, 2 \mathrm{H},-\mathrm{OCH} \mathrm{O}_{2}\right), 6.96(\mathrm{~d}$, $2 \mathrm{H}), 7.13(\mathrm{~d}, 1 \mathrm{H}), 7.33(\mathrm{t}, 1 \mathrm{H})\left(2 \mathrm{C}_{6} \mathrm{H}_{4}\right), 7.37\left(\mathrm{~s}, 1 \mathrm{H}, \mathrm{C}_{3} \mathrm{HS}_{3}\right), 7.56-7.65(\mathrm{~m}, 3 \mathrm{H}), 8.8(\mathrm{~d}, 1 \mathrm{H})\left(2 \mathrm{C}_{6} \mathrm{H}_{4}\right)$. ${ }^{13} \mathrm{C}-\mathrm{NMR}\left(\mathrm{CDCl}_{3}\right) \delta 21.0,65.7,66.4,82.3,115.6,121.7,124.1,124.7,126.2,128.6,132.2,134.8$, 134.9, 151.2, 153.9, 161.5, 162.6, 169.7, 172.7, 215.2. MS (CI) $m / z 507(\mathrm{M}+1)^{+}$. Anal. $\left(\mathrm{C}_{22} \mathrm{H}_{18} \mathrm{O}_{8} \mathrm{~S}_{3}\right): \mathrm{C}$, H, N.

\section{Evaluation of stability in buffered solutions and in human serum.}

Hydrolysis in acidic medium ( $p H$ 1.0) and in phosphate buffer (pH 7.4). A $2 \mathrm{~mL}$ aliquot of $0.5 \mathrm{mM}$ solution of each compound in DMSO was diluted to $10 \mathrm{~mL}$ using $\mathrm{HCl} 0.1 \mathrm{M}$ to reach $\mathrm{pH} 1.0$ or phosphate buffer $50 \mathrm{mM}$ to obtain $\mathrm{pH}$ 7.4. The resulting solution was maintained at $37 \pm 0.5^{\circ} \mathrm{C}$ and at appropriate time intervals a $20 \mu \mathrm{L}$ aliquote of reaction solution was analysed by RP-HPLC. All experiments were performed in triplicate.

Hydrolysis in human serum. A solution of each compound (10 mM) in DMSO was added to human serum (sterile-filtered from human male AB plasma, Sigma-Aldrich) preheated at $37^{\circ} \mathrm{C}$; the final concentration of the compound was $200 \mu \mathrm{M}$. The resulting solution was incubated at $37 \pm 0.5^{\circ} \mathrm{C}$ and at appropriate time intervals $300 \mu \mathrm{L}$ of the reaction mixture was withdrawn and added to $300 \mu \mathrm{L}$ of acetonitrile containing $0.1 \%$ trifluoroacetic acid in order to deproteinize the serum. The sample was sonicated, vortexed and then centrifuged for $10 \mathrm{~min}$ at $2150 \mathrm{~g}$, the clear supernatant was filtered by $0.45 \mu \mathrm{m}$ PTFE filters (Alltech) and analysed by RP-HPLC. All experiments were performed at least in triplicate. 
The reverse-phase HPLC procedure allowed separation and quantitation of the remaining compound and of the products of hydrolysis (aspirin, salicylic acid, salicylate and hydroxy derivatives bearing NOdonor or $\mathrm{H}_{2} \mathrm{~S}$-donor moieties). HPLC analyses were performed with a HP 1100 chromatograph system (Agilent Technologies, Palo Alto, CA, USA) equipped with a quaternary pump (model G1311A), a membrane degasser (G1379A), a diode-array detector (DAD) (model G1315B) integrated in the HP1100 system. Data analysis was done using a HP ChemStation system (Agilent Technologies). The injection volume was $20 \mu \mathrm{L}$ (Rheodyne, Cotati, CA). The analytical column was a Nucleosil 100-5C18 Nautilus $(250 \times 4.6 \mathrm{~mm}, 5 \mu \mathrm{m}$ particle size) (Macherey-Nagel) eluting with a flow-rate of $1.2 \mathrm{~mL} / \mathrm{min}$. The samples were analysed using a gradient method employing a mobile phase consisting of acetonitrile/water with $0.1 \%$ trifluoroacetic acid 55/45 over the first 4 min, grading to $70 / 30$ to 6 min, keeping 70/30 until $15 \mathrm{~min}$ and then back to 55/45 to $20 \mathrm{~min}$. The column effluent was monitored at 226 $\mathrm{nm}$ (for compounds, aspirin and NO-donor or $\mathrm{H}_{2} \mathrm{~S}$-donor hydroxy derivatives) and at $240 \mathrm{~nm}$ (for salicylic acid and salicylates) referenced against a $600 \mathrm{~nm}$ wavelength. Quantitation was done by comparison of peak areas with standards chromatographed under the same conditions.

\section{Inhibition of Platelet Aggregation in vitro.}

Venous blood samples were obtained from healthy volunteers who had not taken any drug for at least two weeks. Volunteers, who were treated according to Helsinki protocol for biomedical experimentation, gave their informed consent to the use of blood samples for research purposes. Platelet rich plasma (PRP) was prepared by centrifugation of citrated blood at $210 \mathrm{~g}$ for $20 \mathrm{~min}$. Aliquots $(500 \mu \mathrm{L})$ of PRP were added into aggregometer (Chrono-log 4902D) cuvettes and aggregation was recorded as increased light transmission under continuous stirring $(1000 \mathrm{rpm})$ at $37^{\circ} \mathrm{C}$ for $10 \mathrm{~min}$ after addition of the stimulus. Collagen at submaximal concentration $(0.8-1.5 \mu \mathrm{g} / \mathrm{mL})$ was used as a platelet activator in PRP. Compounds under study were preincubated with PRP 10 min before addition of the stimulus (collagen). Vehicle alone (0.5\% DMSO) added to PRP did not affect platelet function in control samples. At least 5 experiments for each compound were performed. 
The antiaggregatory activity of tested compounds is evaluated as \% inhibition of platelet aggregation compared to control samples. For most active compounds $\mathrm{IC}_{50}$ values could be calculated by non-linear regression analysis, otherwise $\%$ inhibition at maximal concentration tested $(300 \mu \mathrm{M})$ is reported.

\section{Vasodilator Activities.}

Thoracic aortas were isolated from male Wistar rats weighing 180 - $200 \mathrm{~g}$. As few animals as possible were used. The purposes and the protocols of our studies have been approved by the Ministero della Salute, Rome, Italy. The endothelium was removed, the vessels were cut helically and four-six strips were obtained from each aorta. The tissues were mounted under $1.0 \mathrm{~g}$ tension in organ baths containing $30 \mathrm{~mL}$ of Krebs-bicarbonate buffer with the following composition (mM): $\mathrm{NaCl} 111.2, \mathrm{KCl} 5.0, \mathrm{CaCl}_{2}$ 2.5, $\mathrm{MgSO}_{4} 1.2, \mathrm{KH}_{2} \mathrm{PO}_{4} 1.0, \mathrm{NaHCO}_{3} 12.0$, glucose 11.1 , maintained at $37{ }^{\circ} \mathrm{C}$ and gassed with $95 \% \mathrm{O}_{2}-5 \% \mathrm{CO}_{2}(\mathrm{pH}=7.4)$. The aortic strips were allowed to equilibrate for $1.5 \mathrm{~h}$ and then contracted with $1 \mu \mathrm{M} \mathrm{L}$-phenylephrine or $25 \mathrm{mM} \mathrm{KCl}$. When the response to the agonist reached a plateau, cumulative concentrations of the vasodilating agent were added. Results are expressed as $\mathrm{EC}_{50} \pm \mathrm{SEM}$ $(\mu \mathrm{M})$. The effects of $1 \mu \mathrm{M}$ ODQ or $10 \mu \mathrm{M}$ glibenclamide on relaxation were evaluated in a separate series of experiments in which it was added 5 min before the contraction. With this protocol the inhibitor is preincubated for at least 30 min before the addition of the vasodilator compound. Responses were recorded by an isometric transducer connected to the MacLab System PowerLab. Addition of the drug vehicle, DMSO, had no appreciable effect on contraction level. At least 5 experiments for each compound were performed. 


\section{Supplementary references}

(1) Kawashima, Y.; Ikemoto, T.; Horiguchi, A.; Hayashi, M.; Matsumoto, K.; Kawarasaki, K.; Yamazaki, R.; Okuyama,S.; Hatayama, K. Synthesis and pharmacological evaluation of (nitrooxy)alkyl apovincaminate. J. Med. Chem. 1993, 36, 815-819.

(2) Dunstan, I.; Griffiths, J. V.; Harvey, S.A. Nitric esters. Part I. Characterisation of the isomeric glycerol dinitrates. J. Chem. Soc., 1965, 1319-1324.

(3) Boschi, D.; Tron, G. C.; Lazzarato, L.; Chegaev, K.; Cena, C.; Di Stilo, A.; Giorgis, M.; Bertinaria, M.; Fruttero, R.; Gasco, A. NO-donor phenols: a new class of products endowed with antioxidant and vasodilator properties. J. Med. Chem., 2006, 49, 2886-2897.

(4) Li, L.; Rossoni, G.; Sparatore, A.; Lee, L. C.; Del Soldato, P.; Moore, P. K. Antiinflammatory and gastrointestinal effects of a novel diclofenac derivative. Free Radic. Biol. Med., 2007, 42, 706-719.

(5) Folkmann, M.; Lund, F. J. Acyloxymethyl carbonochloridates. New intermediates in prodrug synthesis. Synthesis 1990, 12, 1159-1166. 